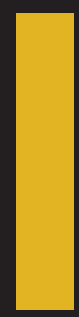

CHANGING LABOR RELATIONS IN THE OTTOMAN EMPIRE AND TURKEY

edited by Karin Hofmeester and Jan Lucassen

ORAL HISTORY AND INDIAN LABOR HISTORY edited by Prasannan Parthasarathi

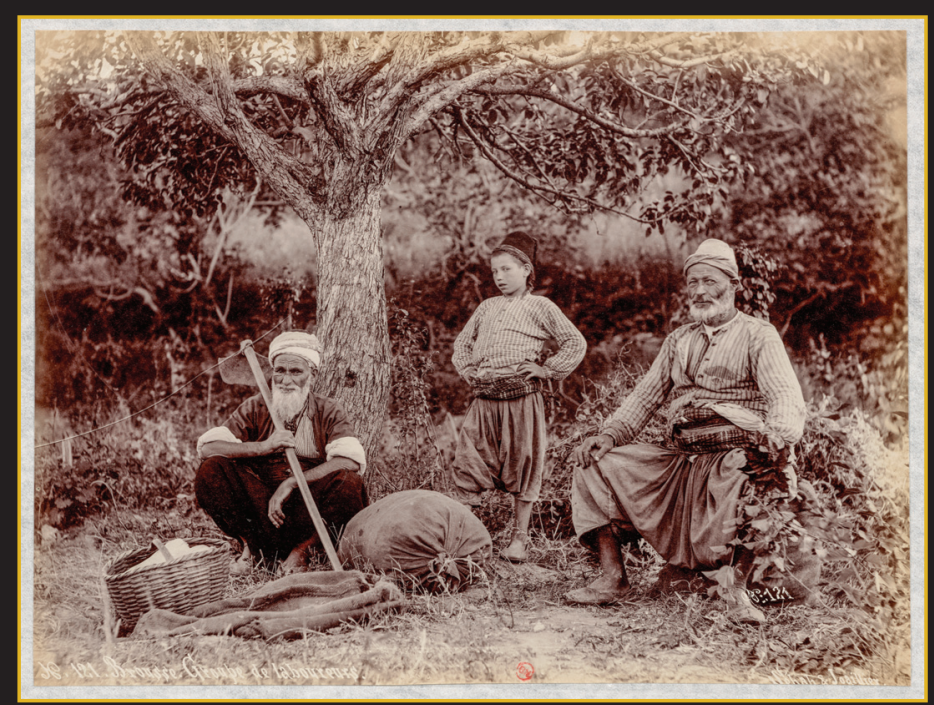

Number 97

Spring 2020
CAMBRIDGE UNIVERSITY PRESS 


\section{SENIOR EDITORS}

Franco Barchiesi

Ohio State University

Kate Brown

Massachusetts Institute of Technology, Cambridge

Barbara Weinstein New York University

\section{ASSOCIATE EDITOR}

Marcel van der Linden International Institute of Social History, Amsterdam

\section{REVIEW EDITOR}

Thai Jones

Columbia University

\section{MANAGING EDITOR}

Fabiola Enríquez

Columbia University

\section{EDITORIAL BOARD}

Aaron Benanav

University of Chicago

Carolyn Brown Rutgers University

Jacob Eyferth

University of Chicago

Lori Flores

Stony Brook University

Marjoleine Kars

University of Maryland

Baltimore County (UMBC)

Jennifer Klein

Yale University
Talitha LeFlouria

Mae Ngai

Columbia University

Mary Nolan

New York University

Prasannan Parthasarathi Boston College

Amy Stanley Northwestern University

Peter Winn

Tufts University

Xiaodan Zhang York College, CUNY
University of Virginia

\section{EDITORS EMERITUS}

Ira Katznelson

Columbia University

International Labor and Working-Class History (ISSN 0147-5479) is published twice yearly, in the spring and the fall, by Cambridge University Press for the editors of $I L W C H$. Annual subscription rates for Numbers 93 and 94 , Spring and Fall (2018): Institutional subscription rates, print and online: US \$222 in the USA, Canada, and Mexico; UK $£ 138$ + VAT elsewhere. Institutional subscription rate, online only: US \$178 in the USA, Canada, and Mexico; UK $£ 109$ + VAT elsewhere. Institutional subscription rate, print only: US \$120 in the USA, Canada, and Mexico; UK $£ 124$ + VAT elsewhere. Individuals subscription rate, print only: US \$56 in the USA, Canada, and Mexico; UK $£ 24$ + VAT elsewhere. Prices include surface postage. International Labor and Working-Class History is indexed in ABC-CLIO; Alternative Press Index; American Bibliography of Slavic and East European Studies; America: History and Life; Arts and Humanities Citation Index; Current Contents: Arts and Humanities; Historical Abstracts; Left Index; Middle East: Abstracts and Index; and Sociological Abstracts.

Editorial Office: Manuscripts, editorial correspondence, and books for review should be addressed to Managing Editor, International Labor and Working-Class History, Columbia University, 1180 Amsterdam Avenue, Box \#60, MC: 2569, New York, NY, 10027 USA or via email: ILWCH@columbia.edu

Publishing, Subscription, and Advertising Offices: Cambridge University Press, One Liberty Plaza, $20^{\text {th }}$ Floor, New York, NY 10006. Tel: 1-800-872-7423. Fax: 1-212-337-5959; or Cambridge University Press, University Printing House, Shaftesbury Road, Cambridge CB2 8BS, UK. Tel: +44(0) 223325806. Fax: +44(0)223 315052. E-mail: journals_marketing@cambridge.org. See also http://www.cambridge.org.

Copyright (C) 2020 International Labor and Working-Class History, Inc. All rights reserved. No part of this publication may be reproduced, in any form or by any means, electronic, photocopying or otherwise, without permission in writing from Cambridge University Press. Photocopying information for users in the USA: The Item-Fee Code for this publication (ISSN 0147-5479/15 \$15.00) indicates that copying for internal or personal use beyond that permitted by Sec. 107 or 108 of the US Copyright Law is authorized for duly registered with the Copyright Clearance Center (CCC) Transaction Reporting Service, provided that the appropriate remittance of $\$ 15.00$ per article is paid directly to: CCC, 222 Rosewood Drive, Danvers, MA 01923. Specific written permission must be obtained for all other copying.

The Board of Consulting Editors may be found immediately following the contents. See the back inside cover of the journal for information concerning submissions to the journal.

Cover Image: (C) Bibliothèque nationale de France. Collection: Photographies positives. Oeuvre de Pascal Sebah, de Sebah et Joaillier, de Jean-Pascal Sebah, de Cosmi Sebah et Cie NQ-D-034366 / Brousse. Groupe de Laboureurs (numéro 121) 


\section{CHANGING LABOR RELATIONS IN THE OTTOMAN EMPIRE AND TURKEY}

Shifting labor relations in the Ottoman Empire and Turkey 1500-2000:

An Introduction

Karin Hofmeester and Jan Lucassen

Ottoman Tax Registers as a Source for Labor Relations in

Ottoman Bursa

Karin Hofmeester and Jan Lucassen

Slavery and Decline of Slave-Ownership in Ottoman Bursa 1460-1880 Hülya Canbakal and Alpay Filiztekin

In Between Market and Charity: Child Domestic Work and Changing Labor Relations in Nineteenth-Century Ottoman Istanbul Yahya Araz and Irfan Kokdaş

\section{ORAL HISTORY AND INDIAN LABOR HISTORY}

Matters of the Heart: Romance, Courtship and Conjugality in Contemporary Delhi Rukmini Barua

Segmented Possibilities: Migrant Life Histories of Hindustani Workers in Post-Colonial India

Camille Buat

\section{STATE OF THE FIELD}

Communism, Cold War and Commodity Chains: Southeast Asian Labor History in a Comparative and Transnational Perspective Ulbe Bosma 


\section{REPORTS FROM THE FIELD}

Historical Cultures Under Conditions of Deindustrialization Working Group Report

George Steve Jaramillo, Melinda Harlov-Csortán, Stefan Moitra and Roberta Garruccio

"German Labour History is Back"-Announcing the Foundation of the German Labour History Association

Stefan Berger

Labor Relations and Slavery in Contemporary Brazil: A New Digital Collection

Silvia Hunold Lara and Nauber Gavski da Silva

\section{REVIEW ESSAY}

Police Work, Unbounded

Kirsten Weld

Louise Audino Tilly: an appreciation - CORRIGENDUM

Miriam Cohen

Contributors 


\section{BOARD OF CONSULTING EDITORS}

Risto Alapuro

University of Helsinki

Kathryn Amdur

Emory University

Eric Arnesen

The George Washington University

Touraj Atabaki

International Institute of Social History,

Amsterdam

Joel Beinin

Stanford University

Gerd Callesen

Arbejderbevaegelsens Bibliotek og Arkiv,

Copenhagen

Jane Caplan

St. Antony's College, Oxford

Frederick Cooper

New York University

Jefferson Cowie

Cornell University

Patrizia Dogliani

University of Bologna

Geoff Eley

University of Michigan

Elizabeth Faue

Wayne State University

Paulo Fontes

Universidade Federal do Rio de Janeiro

Joshua Freeman

CUNY Graduate Center

John French

Duke University

Patrick Fridenson

Ecole des Hautes Etudes en Sciences

Sociales

Wendy Z. Goldman

Carnegie Mellon University

Andrew Gordon

Harvard University

Linda Gordon

New York University
Rick Halpern

University of Toronto

Victoria Hattam

New School for Social Research

William P. Jones

University of Wisconsin,

Madison

Don Kalb

Central European University

Linda Kerber

University of Iowa (Emeritus)

Neville Kirk

Manchester Metropolitan University

Deborah Levenson-Estrada

Boston College

Bruce Levine

University of Illinois,

Champaign-Urbana

Earl Lewis

University of Michigan

Nelson Lichtenstein

University California, Santa

Barbara

Mary Jo Maynes

University of Minnesota

Gwendolyn Mink

Independent Scholar

Mary Nash

University of Barcelona

Silke Neunsinger

Labour Movement Archives

and Library, Sweden

Elizabeth Perry

Harvard University

Anson Rabinbach

Princeton University

Pamela Radcliff

University of California, San Diego

Dilip Simeon

Aman Trust 